\title{
Three Perspectives on Canterbury Freshwater Management
}

Freshwater management has attracted more public and media attention in Canterbury than in any other New Zealand region. Public interest peaked with the controversial 2010 dismissal of the elected regional council under special legislation (Environment Canterbury (Temporary Commissioners and Improved Water Management)
Act 2010). For a range of views on these complex issues, we asked three people intimately involved in the process - elected councillor Lan Pham, appointed commissioner Tom Lambie and Ngāi Tahu cultural rights expert Karaitiana Taiuru - to contribute a short essay assessing the Canterbury Water Management Strategy.

\section{The ECan Water Management Strategy Experiment}

\section{the good, the bad and the tipping - what has the last decade of collaborative planning delivered to Waitaha/Canterbury communities?}

$\mathrm{T}$ he Canterbury Water Management Strategy is a collaborative framework of Canterbury's water resources. The framework attempts to capture community values across a wide spectrum in the form of ten 'target areas', including environmental limits, kaitiakitanga, irrigated land area, and seven others. Governance of the strategy rests with the
Canterbury Mayoral Forum (made up of the ten Canterbury mayors and chairs), and Environment Canterbury (ECan) as the regional council. It also involves ten 'zone committees'. These are joint committees of ECan and Canterbury's various city and district councils and comprise a combination of council, rūnanga and community representatives.
The Canterbury Water Management Strategy aims to bring about change to water management in Canterbury. Because I recognise that change isn't easy, I'll start by listing some positives before discussing some of the pitfalls of the last near-decade of the strategy.

Most significantly, the 'environmental limits' and 'ecosystem health and biodiversity' target areas are given statutory effect through the creation of the Canterbury Land and Water 
The ECan Water Management Strategy Experiment: the good, the bad and the tipping - what has the last decade of collaborative planning delivered to Waitaha/Canterbury communities?

projects in each zone every year. Although there has been criticism that this has resulted in 'pepper pot' projects with little strategic guidance, I know of many small restoration and fencing projects which have got off the ground because of the zone committee's support.

- More recently, the Canterbury Water Management Strategy process spawned industry-agreed 'good management practice' which is now required to be demonstrated through farm environment plans for the highest-risk farming activities (namely, those farmers with over 50 ha of irrigation or over 10ha of winter grazing).

These are positive things. However, in 2019 our world is changing. Rapidly. The
For example, the first-order priorities of the Canterbury Water Management Strategy are the environment, customary use and drinking water (community and stock). Given this, it is perhaps surprising that our environmental, kaitiakitanga and drinking water targets lag greatly in showing tangible improvements (ibid.). Taking the 'environment' target as an example: ECan's latest (2019) annual groundwater survey from 2008-2018 data revealed that nitrate exceeds ecological thresholds in $75 \%$ of the monitored groundwater that feeds surface water and that, overall, nitrate concentrations are increasing.

The change occurring under the Canterbury Water Management Strategy may be worthy in terms of 'holding the line'

\section{The change occurring under the Canterbury Water Management Strategy may be worthy in terms of "holding the line' on environmental decline, but this is an optimistic view.}

latest IPCC report signalled that we have 12 years to avoid climate catastrophe and the associated effects on the water cycle. Global biodiversity loss is now at crisis levels and the United Nations has acknowledged that humanity itself is threatened. We know the pressures on our precious freshwater ecosystems are only going to increase. So how and why does the Canterbury Water Management Strategy fall short in addressing the major challenges we face?

In my view, the primary problem with the strategy is that it perpetuates the commonly spouted myth that we can 'balance' the environment with the economy. The ten target areas are intended to be achieved concurrently, but in reality some target areas have been advanced (either intentionally or unintentionally, as some are much more complex than others) while others are either lagging, completely unresourced, or put in the 'too hard' basket (Environment Canterbury, 2017). on environmental decline, but this is an optimistic view. The change is not happening fast enough to fill the chasm between some positive on-farm changes and industry improvements and actual ecologically meaningful environmental improvement.

Perhaps the biggest flaw in the implementation of the strategy is the priority given to 'farm operating surplus' during the sub-regional plan development phase with the zone committees, and the lack of consideration of economic externalities (such as the cost of environmental restoration or lost recreational or cultural values). My own experience on the Ōrari Temuka Ōpihi Pareora Zone Committee confirmed that, when push comes to shove, 'farm operating surplus' trumps all other values.

I think the most glaring case is found in the Selwyn Waihora zone, however. A recent externalities assessment for $\mathrm{Te}$ Waihora/Lake Ellesmere estimated the change in operating surplus of farms in the catchment if the lake was to meet the trophic level index under the National Policy Statement for Freshwater Management (Harris and Davies, 2017). The assessment concluded that, to meet this improved trophic level, all intensive land use in the catchment would need to cease, resulting in an operating surplus loss to the local farmers and industry of around $\$ 300$ million. Alternatively, excess nutrients could be stopped from entering the lake through undertaking large-scale wetland restoration at a cost of around $\$ 380$ million.

The most widely held interpretation of this report was that the results indicated that it was impossible for the lake to meet the trophic levels under the national policy statement due to the economic impact on farmers and industry in the catchment. My interpretation is that the public are effectively subsidising intensive agriculture in that catchment to the tune of \$300-\$380 million per year by allowing an unsustainable land use to continue and that these costs represent the ecological realities which will ultimately be brought to bear on future generations.

Ignoring externalities is also leading towards other perverse outcomes. For example, in the Christchurch-West Melton zone, future nitrate contamination of Christchurch city's drinking water supply is modelled to reach $3.8 \mathrm{mg} / \mathrm{l}$ over the next 50 -plus years, yet our proposed rules for farms in the main contamination source areas ('hot spots') will (if adopted) require only $15 \%$ reductions in nitrogen loss for dairy farms every decade and a 5\% reduction for all other land uses. Christchurch is currently New Zealand's largest metropolitan area with the luxury of a relatively pure untreated drinking water supply, yet we are accepting and justifying this future nitrate contamination on the basis that the proposed rules are pushing the relevant farms as hard as is 'economically possible'. There are fewer than ten farms in the worst contamination hot spots, yet in the planning process to date their operating surplus has effectively been given precedence over the protection of the drinking water of more than 380,000 people. At what point do we decide to broaden our economic considerations to include the whole community and transfer 
the 'risk' burden - which currently rests with the environment and society - onto the commercial activity that is utilising and/or abusing a public resource for private profit?

The lack of environmental and cultural improvement under the Canterbury Water Management Strategy has also resulted in consistent NGO and rūnanga discontent and disengagement. For example, in the latest proposed plan change for the Waimakariri zone the area will see minimum flow increases for only eight of the 17 streams and rivers in the zone by 2032. Both Te Rūnanga ō Arowhenua and Te Ngāi Tūāhuriri formally stated (among other concerns) their lack of support for the minimum flows set in the recommendations made by their respective zone committees in 2018. How can we, and why would we, expect to see meaningful improvement in mahinga kai (traditional food sources) or biodiversity values when we are not even bringing ecologically significant water flows back to our mostly over-allocated catchments? These recommendations are now going through a Resource Management Act process which includes public submissions and hearings by a panel of RMA commissioners in 2019 .
Ultimately, my perspective is that the 'collaborative model' based on a conversation where all ten targets are advanced is fundamentally flawed. How do we account for the immense biodiversity and ecosystem loss which has already taken place? The almost complete and sustained loss of traditional mahinga kai values for the papatipu rūnanga of Ngāi Tahu? The $90 \%$ of wetland ecosystems already drained? The Canterbury Water Management Strategy as currently implemented is a continuation of the thinking that business as usual will somehow deliver us different environmental outcomes. No matter what our 'opinion', we will eventually find that the environment cannot and will not 'compromise' on its ecological limits. In my view, the ecological/ environmental targets need to be prioritised above all others, with all other targets only pursued in a manner that is consistent with the overarching ecological realities.

The collaborative water management strategy process has shown that even if shared values and sentiment exist, they do not in themselves equate to environmental improvement. We need a rethink of society's long-held view that we can 'balance' the environment with the economy and move instead toward a recognition that economic sustainability implicitly requires environmental sustainability at its core. In the context of the Canterbury Water Management Strategy, this means placing greater resourcing and focus on the priority areas of environment, customary use and drinking water and taking seriously, and urgently responding to, the climate and ecological alarm bells that our scientific community and the public are sounding.

\section{References}

Environment Canterbury (2017) Canterbury Water Management Strategy: targets progress report, R17/15, Christchurch: Environment Canterbury

Harris, S. and T. Davies (2017) 'Selwyn Te Waihora Zone: memorandum on the implications of meeting the National Policy Statement for Freshwater Management objectives for lake environments in Te Waihora', Christchurch: Land Water People

\section{Tom Lambie}

\section{The Success of the Canterbury Water Management Strategy}

$\mathrm{T}$ o understand what the collaborative Canterbury Water Management Strategy has achieved we need to look back to the 'water wars' of the 2000s.

During the 2000s, farmers and environmentalists were locked in a fight over water following the disastrous droughts of the late 1990s. Access to water was the goal, but Environment Canterbury's councillors of the time were divided. People were frustrated and could see that the old adversarial ways weren't working; as a

Tom Lambie is an Environment Canterbury councillor.

result, the Canterbury Water Management Strategy was agreed and put in place in 2009 to find a better way to manage fresh water.

In my view, the Canterbury Water Management Strategy has delivered a huge amount and will continue to do so in the coming decades. A lot of what it has 
delivered, however, is intangible: it's the way people interact, receive information, deal with complexity, and make decisions based on the best evidence and shared values rather than a predetermined position.

There is good evidence that we have stopped the long-term decline in water quality and are starting to see environmental and ecological improvements because of the strategy. It has taken more than 150 years to get to this point, however, and our scientists acknowledge that it may take decades to begin to see improvements in the most affected areas. While our monitoring of water quality trends shows ten-year improvements in most aspects, including nitrogen and phosphorus measures (NNN, DIN, total N, total P, DRP), we still have work to do to reduce water turbidity and bacterial contamination. The MCI measures of ecological health which are very sensitive - will also take time to show improvements.

The Canterbury Water Management Strategy is collaborative, which some people have criticised or seen as weak or inconclusive. But collaboration brings certainty, far more so than relying on a court to decide on an environmental issue. Collaboration is about consensus - working with all stakeholders to look at options and agree on preferred solutions. It is not easy and at times the community discussions were very heated, but always managed to find a way forward. The Canterbury Water Management Strategy has brought people together who, previously, would never have talked, let alone understood each other's views. This includes farmers and local iwi, fishers and environmentalists, community leaders and people just wanting to make a difference.

The strategy empowered Environment Canterbury to introduce - in 2012 - the toughest nitrate pollution rules in the country as part of the Canterbury Land and Water Regional Plan. We should remember that the previous regional plan had been ten years in the drafting and was still not operative when commissioners were appointed in 2010. The first thing the Land and Water Regional Plan did was to put a limit on nitrate pollution; that had never been done before in Canterbury. Farmers had to keep their nitrate leaching at or below their average level from the previous four years. The plan also introduced region-wide stock exclusion rules for waterways, a key tool needed to protect streams and rivers. The key issues in Canterbury were and still are sediment, bacterial contamination, and nutrients such as nitrogen and phosphorus.

Several years on, many farmers now need a land-use consent to farm; this includes a farm environment plan subject to an independent audit. We see this holistic and educational approach to environmental management as more like the fence at the top of the cliff, than the (compliance) ambulance at the bottom. While we still have a focus on compliance and come down hard on environmental polluters, the greatest environmental benefits will come from farmers taking responsibility from the start.

The collaborative process really comes to the fore at the catchment level, where the job is to reduce nitrate pollution rather than just hold the line. Environment Canterbury identified the most at-risk catchments and worked with water management committees and communities on the key local issues and potential solutions, well before the planning work started. This process brought together everyone who had an interest in water, including the local iwi who have a very strong voice in freshwater management in Canterbury. This locally led process has allowed us to bring in very tough planning rules to significantly reduce nitrate leaching in some of the most difficult catchments in Canterbury, including Selwyn Waihora, Hinds, lower Waitaki and the Mackenzie, with more to come.

The water management committees have been criticised by some for being too farmer heavy. The reality is they reflect their communities and members are chosen because of their understanding of local issues as well as for being open to the views of others. The committees also include papatipu rūnanga representatives, who have a strong interest in kaitiakitanga in addition to the other nine target areas of the Canterbury Water Management Strategy.

The collaborative, community-focused approach of the water management strategy turns the traditional planning process on its head - issues and potential solutions are identified before plans are written. This results in very robust and wide-ranging discussions, led by the water management committees, and involving communities of interest. The work often includes extensive work on possible scenarios, before a set of detailed recommendations go from the water management committees to Environment Canterbury.

While the planners and scientists are involved from the start of the community process, the draft plan is completed only after the committee's recommendations are received. The draft plan must then go through a full and rigorous Resource Management Act process, including submissions and a public hearing, run, in Canterbury's case, by a panel of independent commissioners. The hearings focus on evidence and what matters under the RMA. While this process takes time, the outcome is a planning regime which better reflects the wishes of the broader community.

Another important change in Canterbury is that consents are being aligned with the ten-year planning time frames. What this means is that when a consent expires and a new consent is required, it will be written under any new rules or limits rather than extending for decades.

In summary, collaboration has helped communities across Canterbury accept that there are serious problems with water quality and ecological health, and that they are part of both the problem and the potential solutions, as well as building a greater understanding of what's needed and the time it will take to achieve meaningful change.

Collaboration has helped connect the planning process with science, with the community and Ngāi Tahu, with stakeholders and advocacy groups, as well as introducing differing voices and viewpoints. We can now use the relationships and trust built through collaboration to deliver the environmental, social, economic, cultural and recreational benefits envisaged in the Canterbury Water Management Strategy. 


\section{Ngāi Tahu Perspectives on Fresh Water}

\section{Introduction}

This article attempts to explain the South Island's largest iwi, Ngāi Tahu, and its complex decision-making process and belief systems around fresh water within its tribal boundaries. Unlike other iwi in New Zealand, who have maintained a traditional tribal structure, Ngāi Tahu have adopted a Western corporate structure that does not always reflect the opinions of its tribal members.

Water is a taonga to Ngāi Tahu, as it is to other iwi. But with generational loss of authority, best practices and partnerships to protect fresh water, Ngāi Tahu have seen the constant degrading of this taonga. There are authorities justifying water quality with new goals while ignoring the fact that our customary food gathering practices ensured that the water was always fresh. These practices that have been followed for centuries by whānau are no longer possible due to pollution.

For Ngāi Tahu, much of its traditional knowledge has been lost. Ngāi Tahu upoko and Canterbury University scholar Professor Te Maire Tau has described that lack of cultural knowledge within the iwi. His statement reinforces the observation of Hirini Mead that, in 1979, it was obvious that few people really understood tikanga (Mead, 2016), and this included our own people. Writes Tau:

By 1996, Ngāi Tahu could no longer boast a native speaker. In 1992 Pani Manawatu, the Upoko of the Ngāi Tu Ahuriri Runanga and last native speaker of the language, died. His death had been preceded by that of his cousin, Rima Te Aotukia Bell (née Pitama), an elder aunt of the writer who was learned in tribal traditions. In 1996 Jane Manahi, a spiritual elder and leader from Tuahiwi, also passed beyond the shaded veil. These deaths and the 1996 Te Runanga o Ngāi Tahu Act saw the end of Ngāi Tahu old and the evolution of a Ngāi Tahu new. Just as the Gauls and Germanic groups de-colonized themselves and rebuilt their world, so too have Ngāi Tahu. (Tau, 2001, p.148)

There have also been 230 years of immigration and missionary influence introducing new religions that taught that Māori religious beliefs were bad. As a result, many Māori adapted to these new religions, leaving behind their traditional knowledge systems and beliefs. There were also several years of government-led cultural assimilation initiatives against Māori, including the forced removal of water rights. Te Maire Tau refers to being a witness in the 1970s and 1980s to the government actively destroying Ngāi Tahu communities with their 'white death machine', attacking Ngāi Tahu on two fronts: by destroying traditions of mahinga kai and by dismantling fishing camps on the rivers (Tau, 2013, p.15). I argue that current freshwater policies and attitudes that some freshwater pollution is acceptable are just another, but more discreet, 'white death machine' that is enabled due to lack of resources to fight back.

A common argument against tikanga and customary rights is that they are no longer relevant. The same is often said of the Bible and religion. Others believe that the Treaty of Waitangi is also obsolete in this age (Archie, 1995). Tikanga and the Treaty of Waitangi are both relevant and are unique building blocks for modern day

Karaitiana Taiuru whakapapas to Ngāi Tahu (Koukourarata, Puketeraki, Rāpaki, Taumutu, Ngāi Tuāhuriri, Ngāti Waewae, Waihao, Waihopai, Wairewa), Ngāti Rarua, Ngāti Kahungunu (Ngāti Pāhauwera), Ngāti Hikairo (Ngāti Taiuru), Ngāti Tūwharetoa (Ngāti Tamakopiri), Ngāti Hauiti (Ngāti Haukaha) and Ngāti Whitikaupeka.
New Zealand society. For many Māori, traditional tikanga is still applicable and highly relevant; it is handed down through stories in the whānau or, for some, it is just instinct that cannot be described.

Water is as important to Ngāi Tahu and other iwi as land is. We use water to harvest food and for rituals. If the water is polluted, the land is also polluted. Thus, our spiritual, birth and Treaty rights are being denied.

\section{Water is a taonga}

As Te Rūnanga o Ngāi Tahu observes:

Water is central to all Māori life. It is a taonga left by ancestors to provide and sustain life. It is for the present generation, as tangata tiaki [guardians], to ensure that the taonga is available for future generations in as good as, if not better quality. (Te Rūnanga o Ngāi Tahu, 2015)

The definitions of a taonga used by the Waitangi Tribunal mean that any taonga is protected under the guarantees in article 2 of the Māori text of the Treaty of Waitangi, which states:

The Queen of England agrees to protect the chiefs, the subtribes and all the people of New Zealand in the unqualified exercise of their chieftainship over their lands, villages and all their treasures. But on the other hand the Chiefs of the Confederation and all the Chiefs will sell land to the Queen at a price agreed to by the person owning it and by the person buying it (the latter being) appointed by the Queen as her purchase agent.

\section{Kaitiakitanga}

Ngāi Tahu, as other iwi, consider themselves the kaitiaki of the natural world. We have a historical, genealogical and spiritual 
connection to all aspects of the natural world. As kaitiaki, we respect the natural world and ensure that it is being respected and able to be used for future generations. Yet the water authorities have created new criteria to describe what healthy water scientifically is - such as swimmable. This ignores the fact that water can be polluted and considered to be of a safe standard to swim in, yet still too polluted to harvest food from.

In recent times, kaitiaki has become a common term used by bureaucrats in freshwater policies. A kaitiaki is a person, group or being that acts as a carer, guardian, protector and conserver. The gods of the natural world were considered to be the
If Ngāi Tahu were genuine kaitiaki of fresh water, then the water would be better quality and iwi would be able to harvest food from their traditional places.

\section{Ngāi Tahu}

Migrating from the North Island's East Coast over 800 years ago, Ngāi Tahu thrived in Te Wai Pounamu, the South Island. They intermarried with local tribes and adopted their beliefs. Their lands cover much $-80 \%$ - of the South Island, and are New Zealand's largest single tribal territory (Tau, 2015). Ngāi Tahu is the fourth largest Māori iwi.

In the 20 years from 1844, Ngāi Tahu signed formal land sale contracts with the

\section{The definitions of a taonga used by the Waitangi Tribunal mean that any taonga is protected under the guarantees in article 2 of the Māori text of the Treaty of Waitangi ...}

original kaitiaki; for instance, Tāne, god of the forest, was the kaitiaki of the forest. All other kaitiaki emulate those original ones (Mihinui, 2002).

Tau argues that kaitiaki is a term used with such irregularity that it is now meaningless; that today, 'kaitiaki' is used by Māori and Pākehā bureaucrats as a gapfiller to mean everything and yet nothing (Tau, 2013, p.15). But it is a common belief that you cannot be a kaitiaki without being the owner.

Te Rūnanga o Arowhenua are considered the kaitiaki of the Ōpihi and many other rivers within their boundary. These rivers were once a primary source of mahinga kai. Yet today the water flows are so low that the ability to exercise mahinga kai rights is either non-existent or severely restricted. The impacts on the community are devastating. Current generations of whānau can no longer exercise customary rights and the bonding with their waterways that their parents enjoyed as children. Those experiences are now just stories; perhaps one day they will be called legends and folk stories.
Crown for 34.5 million acres of Te Wai Pounamu. The Crown failed to honour its part of those contracts when it did not allocate one-tenth of the land to the iwi as agreed. It also refused to pay a fair price for the land. Robbed of the opportunity to participate in the land-based economy alongside the settlers, Ngāi Tahu became an impoverished and virtually landless tribe. Its full claim involved some 3.4 million acres of lost land, one-tenth of the total Ngāi Tahu land sold. This was the basis of the Ngai Tahu Treaty claim (Te Rūnanga o Ngāi Tahu, n.d.-a).

Today, as an organisation Ngāi Tahu is worth more than $\$ 1.7$ billion, and has numerous corporate and social organisations with their own management and governance structures that sometimes operate in isolation from each other.

\section{Corporate}

Te Rūnanga o Ngāi Tahu (Te Rūnanga), the tribal council, was established by the Te Runanga o Ngai Tahu Act 1996 to be the tribal servant, protecting and advancing the collective interests of the iwi. The Office of Te Runanga o Ngai Tahu is the Ngāi Tahu iwi corporate body.

The Office of Te Rūnanga o Ngāi Tahu is not a traditional iwi structure. It is a Western corporate structure that has ignored tikanga Māori. Eruera Tarena observes that ' $[a]$ dopting Western technical tools has unintentionally resulted in also adopting Western cultural values and practices into the organisation'. He further states: 'There is widespread belief that mimicking Western organisational structures and their associated cultural beliefs risks further assimilation' (Prendergast-Tarena, 2015).

The operations of the Office of $\mathrm{Te}$ Rūnanga o Ngāi Tahu are managed by a chief executive officer and a management team. One of Te Rūnanga's earliest policy decisions was to employ the 'best person for the job', which gave the iwi credibility in the wider society, but resulted in large numbers of non-Māori staff, executives and governors, especially in the investment arm (Prendergast-Tarena, 2015). This makes Ngāi Tahu different from many other iwi organisations, who predominantly employ their own iwi members and retain a tribal knowledge, so that iwi desires are incorporated into decision-making.

Within the Office of Te Rūnanga o Ngāi Tahu, Te Ao Tūroa is the strategic and policy team responsible for the natural environment, including fresh water and mahinga kai. Its general manager reports to the chief executive officer. Te Ao Tūroa leads the strategic direction of the environmental workstreams and ensures the integration of environmental programmes and workstreams within the wider tribal development strategy to support whānau outcomes (Te Rūnanga o Ngāi Tahu, n.d.-b). Te Ao Tūroa consults with 18 regional papatipu rūnanga, often by way of an email requesting information.

Two of the entities of Te Rūnanga o Ngāi Tahu are the self-governing commercial arms Ngāi Tahu Property and Ngāi Tahu Farms. Ngāi Tahu Property and Ngāi Tahu Farms have a mandate to make the iwi money. Not until recently did their decision-making processes consider any cultural values. By default, both of these entities make commercial decisions about fresh water that may contradict iwi values. 
The Ngāi Tahu papatipu boundaries are viewable in the Te Runanga o Ngai Tahu (Declaration of Membership) Order 2001. ${ }^{1}$ There are two marae, in Kaikōura Takahanga - and Mangamanu. The Rūnanga is based at Takahanga.

\section{Decision-making}

What one papatipu rūnanga agrees to and enacts could be very different from what a neighbouring papatipu rūnanga does. This is the traditional customary right of mana whenua. For example, Te Ngāi Tūāhuriri is firmly focused on the relationship between the Treaty of Waitangi and the 1848 Canterbury deed of purchase. With the 1848 Canterbury purchase, the Crown gained substantive sovereignty over the land; however, the deed of purchase did not surrender to the Crown the ownership of water, as occurred in other regions of the South Island and in the North Island. For this reason, aboriginal title to water was not surrendered or extinguished (Tau, 2013, p.12).

Of the ten purchase deeds of land and resources in the Ngāi Tahu tribal boundaries, only four mention water. Regarding the remaining six that did not, it could be argued by the relevant papatipu rūnanga that they have customary rights to water within their tribal boundaries. Yet this is not considered with any partnerships with local council or government.

\section{Whānau and individuals}

Iwi member registrations are over 56,000. The Office of Te Rūnanga o Ngāi Tahu estimates that only about $10 \%$ of registered members are active within a papatipu rūnanga. Member participation is often based on the most influential family at the marae at the time (Prendergast-Tarena, 2015). As a result, experts in various areas of the environment may not necessarily be involved with the rūnanga.

Some whānau have Māori trusts to govern land which has fresh water. The trust authority would override the rūnanga, adding another dimension to the complexities of Ngāi Tahu decision-making around fresh water.

\section{Non-Ngāi Tahu marae}

This is another unique aspect of the geographic area of Ngāi Tahu. There are other marae in the Ngāi Tahu district that are not Ngāi Tahu and do not represent Ngāi Tahu views. These marae are Rehua and Ngā Hau E Whā in Christchurch; Hākatere Marae in Ashburton; Te Aitarakihi Multi Cultural Centre in Timaru; and Araiteuru Marae in Dunedin.

\section{Ngāi Tahu and freshwater resources}

Freshwater fish were among the most important traditional food sources for Ngāi Tahu. Freshwater species, especially tuna, were an important part of Ngāi Tahu dietary requirements; they were plentiful
Ngāi Tahu oppose the Crown's assumption that it can regulate the taking of water without having acquired ownership first, and its assumption that it can create a property right by default, and a commercial value over a resource that can be traded, when it cannot show proof of ownership. Ngāi Tahu protests that the regulations and actual processes have led to the degradation of our waterways and fisheries (Tau, 2013, pp.23).

The vision statement of Te Ao Tūroa, the environment section of Te Rūnanga o Ngāi Tahu, begins:

\section{If waterways are polluted and unhealthy, then Māori people are spiritually unhealthy, Ngāi Tahu and other iwi are not able to exercise their birthright and Treaty right to harvest food from the fresh water, and taonga species are not protected.}

and nutritious, and accessible all over the South Island when people were travelling between sites. Fishing spots were usually on every bend of a river and stream. These fishing spots were inherited from generation to generation based on whakapapa.

Traditional knowledge was also passed down to new generations and many whānau had their own spiritual connections to their fishing spots. Until recently, with the derogation of water quality, these fishing spots were a primary source of food for families.

As an iwi, Ngāi Tahu considers that its relationship with the waters of its rohe has been eroded over the last 150 years. Evidence produced by Ngāi Tahu before the Waitangi Tribunal documented numerous examples of waterways within the Ngāi Tahu rohe that are now severely polluted by discharges, or where reworking of the hydrological regime of waterways has resulted in unnatural patterns of erosion, sedimentation, drying up of flows and damage to rich mahinga kai habitats on the riparian margins ( $\mathrm{Te}$ Rūnanga o Ngāi Tahu, 2015).
Our dream is that our ancestral landscape is protected and our people have living relationships with their whakapapa and traditions through the environment. The goal is that Ngāi Tahu is a principled kaitiaki (steward) of our takiwā (tribal territory). (Te Rūnanga o Ngāi Tahu, n.d.-c)

Current water strategies and policies do not allow for this Ngāi Tahu dream.

\section{Conclusion}

Water is a taonga to all iwi, including Ngāi Tahu. If waterways are polluted and unhealthy, then Māori people are spiritually unhealthy, Ngāi Tahu and other iwi are not able to exercise their birthright and Treaty right to harvest food from the fresh water, and taonga species are not protected.

As the current-day guardians of water, it is our job to ensure that water is healthier than when it was inherited by us.

Current decision-making under the Ngāi Tahu banner may not always be what 
the whānau want or believe. It may be a corporate decision, or a rūnanga may have been overwhelmed with other consultations and feedback and a water decision neglected.
If the quality standard for fresh water is based on the fact that food can be customarily gathered, then fresh water will be of a good enough quality for all New Zealanders, Ngāi Tahu will have their
Treaty and customary rights reinstated, and the country will be able to know that future generations will have access to fresh water.

1 http://www.legislation.govt.nz/regulation /public/2001/0200/latest/whole.html.

\section{References}

Archie, C. (1995) Maori Sovereignty: the Pakeha perspective, Auckland: Hodder Moa Beckett

Mead, H.M. (2016) Tikanga Māori: living by Māori values, revised edn, Wellington: Huia

Mihinui, H. (2002) 'Hutia te rito o te harakeke: a flaxroots understanding of resource management', in M. Kāwharu (ed.), Whenua: managing our resources, Auckland: Reed

Ngata, T. (2002) 'Wai Māori: a Māori perspective on the freshwater debate', The Spinoff, 6 November, https://thespinoff.co.nz/atea/06-112018/wai-maori-a-maori-perspective-on-the-freshwater-debate/

Prendergast-Tarena, E.R. (2015) 'Indigenising the corporation: indigenous organisation design: an analysis of their design, features, and the influence of indigenous cultural values', PhD thesis, University of Canterbury

Tau, T.M. (2001) 'The death of knowledge: ghosts on the plains',
Tau, T.M. (2013) Water Rights for Ngāi Tahu: a discussion paper, Christchurch: Canterbury University Press

Tau, T.M. (2015) 'Ngāi Tahu', Te Ara - the Encyclopedia of New Zealand, http://www. TeAra.govt.nz/en/ngai-tahu

Te Rūnanga o Ngāi Tahu (2015) Freshwater Policy, https://ngaitahu.iwi.nz/ wp-content/uploads/2015/06/ngai-tahu-freshwater-policy.pdf

Te Rūnanga o Ngāi Tahu (n.d.-a) 'Claim history', https://ngaitahu.iwi.nz/ ngai-tahu/the-settlement/claim-history/

Te Rūnanga o Ngāi Tahu (n.d.-b) 'Chief Executive Officer/ Kā Pakitua Leadership Team', https://ngaitahu.iwi.nz/te-runanga-ongai-tahu/chief-executive/

Te Rūnanga o Ngāi Tahu (n.d.-c) 'Te ao tūroa: environmental kaitiakitanga', https://ngaitahu.iwi.nz/environment/

New Zealand Journal of History, 35 (2), pp.131-52

\section{SPECIAL ISSUE OF POLICY QUARTERLY Policy and Family Well-being}

Policy Quarterly invites submissions on a special edition examining the intersection of policy and family wellbeing. This issue will broadly focus on all aspects of family and whānau well-being, with a particular interest in highlighting the diversity in New Zealand family forms and experiences.

We invite original and unpublished submissions

Timeline:

- Deadline for full papers:

18 October, 2019

- Reviews of full papers provided:

22 November, 2019

- Deadline for revised submissions: 17 January, 2020

- Intended journal release date:

February, 2020 of both theoretical/conceptual work and empirical analysis or reviews, so long as policy implications are either explicit (e.g. the analysis examines legislation or programmes targeted at families and children) or connections made clear (e.g. the implications of the research are connected to policy or speak to how the findings can inform policy).

\section{Submission guidelines:}

- Text length should be 4,000 - 5,000 words including references

- Abstract of 150 words maximum

- APA style in-text citations and references

- Double-spaced lines

Full papers will receive double-blind external reviews (1-2 reviews, in addition to the Editor's reading).

For more information on formatting and style, please refer to a recent Policy Quarterly issue:

https://ojs.victoria.ac.nz/pq/index

Dr. Kate Prickett, the Guest Editor of the special issue, welcomes inquiries regarding paper submission:

kate.prickett@vuw.ac.nz 